DOI: $\underline{10.34305 / \text { gemic.v1i1.318 }}$

\title{
THE EFFECT OF HYDROTHERAPY ON THE REDUCTION OF BLOOD PRESSURE IN PREGNANT WOMEN WITH HYPERTENSION AT THE PRIMARY HEALTH CAREASTANAJAPURA CIREBON DISTRICT IN 2019
}

\author{
Larasyati Sholekha, Entin Jubaedah, Lia Nurcahyani \\ Poltekkes Kemenkes Tasikmalaya \\ larasyatis@gmail.com
}

\begin{abstract}
One of the causes of maternal mortality and morbidity is pregnancy induced hypertension $(\mathrm{PIH})$. One of many hypertension management in pregnancy with nonpharmacological is hydrotherapy, which is soaking the feet using warm water for 20 minutes. This study aims to determine the differences in systolic and diastolic blood pressure in the hydrotherapy group with a temperature of $40^{\circ}-43^{\circ}$ compared to temperatures of $37^{\circ}-39^{\circ}$.

The study using Quasi-Experimental non-randomized pre-test and post-test with control design on 22 hypertensive pregnant women using purposive sampling technique. Research instruments included observation sheets, sphygmomanometer, stethoscope, and digital water thermometer. Univariate and bivariate data analysis using the Wilcoxon and Mann-Whitney tests.

This study showed difference of systolic blood pressure $p$ value 0,000 and difference of diastolic $\mathrm{p}$ value 0,013 ( $\mathrm{p}<0,05)$, therefore there were differences in systolic and diastolic blood pressure in the hydrotherapy group with a temperature of $40^{\circ}-43^{\circ}$ compared to $37^{\circ}$ $39^{\circ}$. Hydrotherapy using temperature of $40^{\circ}-43^{\circ}$ is better to use than temperature of $37^{\circ}-$ $39^{\circ}$. Midwives can use hydrotherapy as an early treatment alternative for hypertensive pregnant women.
\end{abstract}

Keywords : Decrease In Blood Pressure; Hydrotherapy; Hypertension; Pregnant Women. 


\section{Introduction}

The maternal mortality rate is very high. According to the World Health Organization in Alkema et al. (2016) worldwide, around 830 women die every day due to complications related to pregnancy or childbirth. It is estimated that in 2015, approximately 303,000 women died during and after pregnancy and childbirth (WHO, 2018). According to (WHO, 2018), $75 \%$ of the causes of maternal mortality in the world are heavy bleeding (mostly bleeding after childbirth), infection (usually after childbirth), high blood pressure during pregnancy (pre-eclampsia and eclampsia), complications from childbirth and unsafe abortion.

Hypertension in Pregnancy (HDK) is one of the causes of maternal morbidity and mortality besides bleeding and infection. In Indonesia, the Maternal Mortality Rate according to the Indonesian Health Demographic Survey (IDHS) in 2012 shows a significant increase, namely 359 maternal deaths per 100,000 live births. MMR again shows a decrease to 305 maternal deaths per 100,000 live births based on the results of the 2015 Inter-Census Population Survey (SUPAS) (Ministry of Health, 2017). Preeclampsia and eclampsia are the causes of $30-40 \%$ of perinatal deaths, while in several Indonesian hospitals it has shifted bleeding as the main cause of maternal death (Fadlun \& Feryanto, 2011). Based on District / City health reports in 2016, in West Java the number of maternal deaths was
799 people $(84.78$ / 100,000 KH) (West Java Provincial Health Office, 2016). In Cirebon Regency in 2015, the number of maternal deaths was recorded as many as 53 people, in 2016 it decreased to 47 people, and in 2017 it decreased again to 39 cases. The highest cause of maternal death in Cirebon Regency in 2017 was eclampsia $44 \%$, bleeding $18 \%$, heart disease $8 \%$, Diabetes Miletus 5\%, infection 2\% and others $23 \%$. In Cirebon Regency, the most cases of hypertension in pregnancy occurred in the Work Area of the Primary Health Care Astanajapura, namely, in 2015 there were 47 cases, in 2016 it had increased to 79 cases, in 2017 it had decreased to 56 cases and in 2018 from January to November there were 76 cases of hypertension in pregnancy have increased.

Blood pressure is the lateral force on the artery wall by blood that is pushed with pressure from the heart (Potter \& Perry, 2010). Blood pressure is measured in units of Hydrargyrum millimeters $(\mathrm{mmHg})$ and recorded in two numbers, namely systolic pressure (when the heart beats) and diastolic pressure (when the heart relaxes) (LeMone, $\&$ Burke, 2008). Hypertension is a medical problem that often occurs during pregnancy and can cause complications in $2-3 \%$ of pregnancies. Hypertension in pregnancy is defined as systolic blood pressure $\geq 140 \mathrm{mmHg}$ and diastolic blood pressure $\geq 90 \mathrm{mmHg}$ (Robson, S. E. \& Waugh, 2013). Hypertensive disorders due to pregnancy induced hypertension (PIH) can cause morbidity / pain 
in the mother (including eclamptic seizures, cerebral hemorrhage, pulmonary edema (fluid in the lungs), acute kidney failure, and blood clots in the blood vessels (Fadlun \& Feryanto, 2011). There is also an impact on perinatal mortality due to conditions associated with placental abruption, intrauterine growth restriction in normal fetuses, and preterm birth. 500-600 babies each year die due to PIH (Medforth et al., 2015).

Hypertension can be treated pharmacologically and non pharmacologically or what is called complementary therapy. Pharmacological treatment of hypertension certainly contains chemicals that can cause side effects, while non-pharmacological treatment is natural treatment including herbal therapy, nutritional therapy, aromatherapy, reflexology massage and foot soaking therapy with warm water (Nurahmandani, A. R., Hartati, E. \& Supriyono, 2016) Hydrotherapy is a therapy that is done by soaking the feet in warm water, this therapy will provide a relaxing effect, reduce pain and increase the ability of the tools to move. Scientifically, warm water has a physiological impact on the body. The hydrostatic pressure of water against the body encourages the enlargement of blood vessels from the legs to the chest cavity and blood will accumulate in the blood vessels of the heart. Warm water will dilate blood vessels, reduce blood viscosity, reduce muscle tension, increase tissue metabolism and increase permeability (Nurahmandani, A. R., Hartati, E. \& Supriyono,
2016). Hydrotherapy or warm water soaking is one type of natural therapy that aims to improve blood circulation, reduce edema, increase muscle relaxation, nourish the heart, relax muscles, relieve stress, muscle aches, relieve pain, increase capillary permeability, provide warmth to body so it is very useful for blood pressure reduction therapy in hypertension (Dilianti, Candrawati, \& W, 2017).

\section{Method}

The research method used is QuasiExperimental non-randomized pre-test and post-test with control group design. This type of research is quantitative with an analytic research design (Arikunto, 2010). This study analyzed the differences in blood pressure in the hydrotherapy group with a temperature of $40^{\circ}-43^{\circ}$ compared to $37^{\circ}-39^{\circ}$.

The population is the entire research subject (Arikunto, 2010) . The population in this study were all pregnant women with hypertension in the working area of the Primary Health Care Astanajapura for the period February s.d. April 2019.

The sample is part or representative of the population under study (Arikunto, 2010). The sampling technique used in this study is the Non Random Sampling technique with purposive sampling, which is a sampling technique with certain considerations (Sugiyono, 2015). The research sample was all pregnant women with hypertension in the work area of the Primary Health Care Astanajapura, 
Cirebon Regency in the period February to April 2019, the sample size was calculated using sample size software based on previous research entitled The Effectiveness of Soaking Feet With Warm Water Against Lowering Blood Pressure in Mothers Pregnancy with Preeclampsia at Ngaliyan Public Health Center Semarang by Sabattani, C. F., Machmudah \& Supriyono, (2016), and a study by Rahim, et al., (2015) entitled the effect of warm foot soaking on changes in blood pressure in pregnant women with hypertension, using the hypothesis test for two population means (one -side test):

$$
n=\frac{2 \sigma^{2}\left(Z_{1-\alpha / 2}+Z_{1-\beta}\right)^{2}}{\left(\mu_{0}-\mu_{a}\right)^{2}}
$$

With a level of significance (\%) $\alpha=5$, power of the test $1-\beta \neg=80$, population standard deviation, $\sigma=5,476$, population variance $\sigma^{\wedge} 2=29.986576$, test value of the population means, $\mu_{-} 0=15,3$, Anticipated population mean, $\mu \_a=9$, obtained a sample of $\mathrm{n}=10$. Then the minimum number of subjects needed is 10 people, taking into account the drop out rate of $10 \%$ ( $f=0.1$ ), then the estimated study subjects are calculated based on formula:

$$
n^{\prime}=\frac{n}{(1-f)}
$$

Then the minimum number of samples in this study for each group is 11 people. If it is assumed that the number of hypertensive pregnant women who get hydrotherapy with a temperature of $40^{\circ}-43^{\circ}$ and a temperature of $37^{\circ}-39^{\circ}$, the estimated minimum total sample size is 22 people.

Data collection uses primary data and secondary data. Secondary data is data obtained from village midwives at the Primary Health Care Astanajapura regarding pregnant women with hypertension or blood pressure $\geq 140 / 90$ $\mathrm{mmHg}$ as respondents for the period February to April 2019. Primary data is about the identity of the respondent, and the results of blood pressure measurements taken before and after the intervention was given at the respondent's house using an observation sheet.

Researchers conducted blood pressure checks using a sphygmomanometer and a stethoscope on the respondents, the results were recorded on the observation sheet. The respondent's family or companion prepares warm water, a bucket for soaking the feet and preparing a closed room. Researchers measured the temperature of the water using a digital water thermometer. Warm water in group I with a temperature of $40^{\circ}-43^{\circ}$ and group II with a temperature of $37^{\circ}-39^{\circ}$. Water is poured into the bucket. After that, a hydrotherapy intervention was carried out, namely soaking the mother's feet to the top of her ankles for 20 minutes in a bucket of warm water that had been prepared. Tidy up used tools and encourage the mother to rest for 30 minutes. After completion, the researchers conducted blood pressure checks on respondents, the results were recorded on the 
observation sheet. This treatment is only done once while the mother is at rest. the classification of hypertension, age, and parity, is as follows:

\section{Results}

The description of the characteristics of pregnant women with hypertension based on

Table 1. Frequency Distribution of Pregnant Women with Hypertension Based on the Classification of Hypertension, Age and Parity in the Work Area of the Primary Health Care Astanajapura Cirebon Regency in 2019

\begin{tabular}{ccc}
\hline Variable & Frequency & Percentage (\%) \\
\hline Classification of Hypertension & 2 & \\
Chronic Hypertension & 19 & 9.1 \\
Gestational Hypertension & 1 & 46.4 \\
Peeclampsia & 22 & 100 \\
Total & & \\
Age (Years) & 15 & 68,2 \\
$21-35$ & 7 & 31,8 \\
$>35$ & 22 & 100 \\
Total & & \\
Parity & 3 & 13,6 \\
Primipara & 18 & 81,8 \\
Multipara & 1 & 4,5 \\
Grandemultipara & 22 & 100 \\
Total & &
\end{tabular}

Normality test is the distribution to determine the distribution of normal or abnormal data. Data presentation and hypothesis testing depend on whether the data is normal or not. For data presentation, if the distribution is normal, use means and standard deviations. If the distribution is not normal, use the median and percentile. To test the hypothesis, if the distribution is normal, use a parametric test. If the distribution is abnormal, use a non-parametric test. Normality test using Shapiro-wilk if n 50 (Dahlan, 2017).

Table 2. Normality Distribution using Shapiro-Wilk on the Difference in Systolic and Diastolic Blood Pressure Pregnant Women with Hypertension with Hydrotherapy in the Work Area of the Primary Health Care Astanajapura Cirebon Regency in 2019

$$
\text { N Median Mean P }
$$

(Minimum-Maksimum)

\begin{tabular}{|c|c|c|c|c|}
\hline \multirow[t]{2}{*}{$\begin{array}{l}\text { Pre-test } \\
\text { Sistolik }\end{array}$} & Negative Ranks & $11^{\mathrm{a}}$ & $\begin{array}{c}140 \\
(140-180)\end{array}$ & 150.91 \\
\hline & Positive Ranks & $0^{b}$ & & 0.003 \\
\hline
\end{tabular}


DOI: $\underline{10.34305 / g e m i c . v 1 i 1.318}$

\begin{tabular}{|c|c|c|c|c|c|}
\hline \multirow[t]{2}{*}{$\begin{array}{l}\text { Post-test } \\
\text { Sistolik }\end{array}$} & Ties & $0^{\mathrm{c}}$ & \multirow[t]{2}{*}{$\begin{array}{c}130 \\
(110-170)\end{array}$} & \multirow[t]{2}{*}{134,91} & \\
\hline & Total & 11 & & & \\
\hline \multirow{2}{*}{$\begin{array}{l}\text { Pre-test } \\
\text { Diastolik }\end{array}$} & Negative Ranks & $9^{\mathrm{d}}$ & 90 & 94,55 & \\
\hline & Positive Ranks & $0^{\mathrm{e}}$ & & & 0.005 \\
\hline \multirow[t]{2}{*}{$\begin{array}{l}\text { Post-test } \\
\text { Diastolik }\end{array}$} & Ties & $2^{f}$ & $\begin{array}{c}84 \\
(70-100)\end{array}$ & 86,18 & \\
\hline & Total & 11 & & & \\
\hline
\end{tabular}

Table 3. Results of Wilcoxon Test Analysis for Systolic and Diastolic Variables in Pregnant Women with Hypertension by Giving Hydrotherapy Using a Temperature of $37^{\circ}-39^{\circ}$ in the Work Area of the Primary Health Care Astanajapura Cirebon Regency in 2019

\begin{tabular}{lccc}
\hline & Median (Minimum-Maksimum) & Mean Rank & P \\
\hline $\begin{array}{l}\text { Temperature } \\
40^{\circ}-43^{\circ}\end{array}$ & $16(10-30)$ & 16.55 & \\
\hline $\begin{array}{l}\text { Temperature } \\
37^{\circ}-39^{\circ}\end{array}$ & $6(2-10)$ & 6.45 & 0.000 \\
\hline
\end{tabular}

Table 4. Results of the Mann-Whitney Test Analysis Based on the Difference in Systolic Blood Pressure in Pregnant Women with Hypertension by Giving Hydrotherapy Using Temperatures of $40^{\circ}-43^{\circ}$ and $37^{\circ}-39^{\circ}$ in the Work Area of the Primary Health Care Astanajapura Cirebon Regency in 2019

\begin{tabular}{|c|c|c|c|c|c|}
\hline & & $\mathbf{N}$ & $\begin{array}{c}\text { Median } \\
\text { (Minimum-Maksimum) }\end{array}$ & Mean & $\mathbf{P}$ \\
\hline \multirow[t]{2}{*}{$\begin{array}{l}\text { Pre-test } \\
\text { Sistolik }\end{array}$} & Negative Ranks & $11^{\mathrm{a}}$ & $\begin{array}{c}140 \\
(140-150)\end{array}$ & 141,82 & \\
\hline & Positive Ranks & $0^{b}$ & & & 0.003 \\
\hline \multirow[t]{2}{*}{$\begin{array}{l}\text { Post-test } \\
\text { Sistolik }\end{array}$} & Ties & $0^{\mathrm{c}}$ & $\begin{array}{c}134 \\
(130-148)\end{array}$ & 136,64 & \\
\hline & Total & 11 & & & \\
\hline \multirow[t]{2}{*}{$\begin{array}{l}\text { Pre-test } \\
\text { Diastolik }\end{array}$} & Negative Ranks & $8^{d}$ & $\begin{array}{c}90 \\
(80-90)\end{array}$ & 89,09 & \\
\hline & Positive Ranks & $0^{\mathrm{e}}$ & & & 0.011 \\
\hline \multirow[t]{2}{*}{$\begin{array}{l}\text { Post-test } \\
\text { Diastolik }\end{array}$} & Ties & $3^{f}$ & $\begin{array}{c}84 \\
(80-100)\end{array}$ & 84,91 & \\
\hline & Total & 11 & & & \\
\hline
\end{tabular}

Table 5. Results of the Mann-Whitney Test Analysis Based on the Difference in Diastolic Blood Pressure in Pregnant Women with Hypertension by Giving Hydrotherapy Using Temperatures of $40^{\circ}-43^{\circ}$ and $37^{\circ}-39^{\circ}$ in the Work Area of the Primary Health Care Astanajapura Cirebon Regency in 2019 
DOI: $\underline{10.34305 / \text { gemic.v1i1.318 }}$

\begin{tabular}{lccc}
\hline & Median (Minimum-Maksimum) & Mean Rank & $\boldsymbol{P}$ \\
\hline $\begin{array}{l}\text { Temperature } \\
40^{\circ}-43^{\circ}\end{array}$ & $10(0-16)$ & 14.86 & \\
\hline $\begin{array}{l}\text { Temperature } \\
37^{\circ}-39^{\circ}\end{array}$ & $6(0-8)$ & 8.14 & 0.013 \\
\hline
\end{tabular}

\section{Discussion}

Based on table 1, it can be seen that most pregnant women in the work area of the Primary Health Care experienced gestational hypertension, as many as 19 people $(86.4 \%)$, while 2 people with chronic hypertension $(9.1 \%)$, and 1 person with mild preeclampsia (4). 5\%). Most pregnant women experience gestational hypertension starting from gestational age > 20 weeks. According to the theory, gestational hypertension is hypertension without proteinuria after 20 weeks of gestation and disappears after delivery. Chronic hypertension is hypertension without proteinuria that arises from before pregnancy and persists after delivery. (Ministry of Health of the Republic Indonesia, 2017).

This study is in line with research conducted by Rahim et al., (2015), entitled The Effect of Warm Water Foot Soak on Changes in Blood Pressure of Pregnant Women with Hypertension, the results of the study are the history of hypertension in third trimester pregnant women who experience hypertension in the Kahuripan
Health Center Work Area is in the gestational category. namely as many as 15 people $(88.2 \%)$.

Based on table 2, it can be seen that the majority of pregnant women experiencing hypertension are at the age of 21-35 years, namely 15 people (68.2\%), while age $>35$ are 7 people $(31.8 \%)$. The results of this study are supported by research conducted by (Jumaiza, et al., 2018) with the title Analysis of Factors Associated with the Incidence of Hypertension in Third Trimester Pregnant Women, the results of research on age with hypertension in pregnancy, most of the respondents were 24 people (60\%) 20-35 years old. Researchers argue that pregnant women can experience pregnancy hypertension at a young or old age. The possibility that can cause most pregnant women to experience gestational hypertension at the age of $20-35$ years is a lack of knowledge about the physiology of pregnancy so that the mother feels afraid something will happen to her pregnancy. This can affect the mother's subconscious, causing anxiety that causes the mother to 
lack sleep or rest. Therefore, pregnant women should immediately check their pregnancy when they feel signs of pregnancy in order to get more complete information about pregnancy and the danger signs of pregnancy are detected as early as possible.

Based on table 3, it can be seen that most pregnant women experience hypertension, namely multiparous as many as 15 people $(81.8 \%)$, while primipara as many as 3 people (13.6\%), and grandemultipara as many as 1 person $(4.5 \%)$. The results of this study are in line with the research of (Jumaiza, Elvira, D. \& Panjaitan, 2018). Based on the results of research on parity with hypertension in pregnancy, some of the respondents, namely 23 people $(57.5 \%)$ were included in multigravida and 17 people $(42.5 \%)$ were primigravida. However, the results of this study are not in line with research conducted by Imaroh, (2018), showing that the incidence of hypertension in pregnant women is more common in the primigravida group of 16 respondents $(72.7 \%)$, compared to the multigravida group of 6 respondents $(27.3 \%)$. The researcher argues that most pregnant women with hypertension are multiparous due to several possible factors, namely the distance between pregnancy is too close from the last child, and environmental conditions that are less supportive during pregnancy, for example, husbands are busy working while pregnant women have to do their own homework plus bother taking care of them. young children. Therefore, it is important to plan a healthy pregnancy by managing the distance between pregnancies, and the role of the family, especially the husband, can help ease the work of pregnant women.

Based on table 4 , it can be seen that the Wilcoxon test shows that the average blood pressure value of pregnant women with hypertension before being given hydrotherapy is systolic $150.91 \mathrm{mmHg}$, and diastolic is $94.55 \mathrm{mmHg}$. The average blood pressure of pregnant women with hypertension after hydrotherapy was given, namely systolic of $134.91 \mathrm{mmHg}$ and diastolic of $86.18 \mathrm{mmHg}$. So that the difference between the decrease in blood pressure of pregnant women and hypertension is $16 \mathrm{mmHg}$ systolic and 8 $\mathrm{mmHg}$ diastolic. From these data it can be seen that there is a decrease in blood pressure of pregnant women with hypertension after being given hydrotherapy. Systolic blood pressure in respondents after being given hydrotherapy 
completely decreased (100\%), while diastolic blood pressure as many as 9 people (81.8\%) experienced a change, and as many as 2 people (18.2\%) did not change. The results of the Wilcoxon test study showed that the systolic results were p $0.003(<0.05)$ and the diastolic p 0.005 $(<0.05)$, so that there was a statistically significant difference before and after the intervention on systolic and diastolic blood pressure.

The results of the research analysis are in accordance with the research conducted by Rahim et al., (2015). The research method used was an experiment with a pre-experimental research type with a one group pre-test and post-test approach. The study population was all pregnant women with hypertension as many as 24 people. Sampling technique using accidental sampling technique that is as many as 17 people. The results showed that the average blood pressure before being given warm water foot bath therapy (using a water temperature of $40^{\circ}$ ), systolic was $144.7 \mathrm{mmHg}$, and diastolic was 92.9 $\mathrm{mmHg}$. The average blood pressure after therapy was $129.4 \mathrm{mmHg}$ systolic and 87.6 $\mathrm{mmHg}$ diastolic. The results showed that the significance value of systolic blood pressure was 0.000 and diastolic blood pressure was 0.003, ( $\mathrm{p}<0.05$ ), so $\mathrm{H}_{0}$ was rejected, meaning that there was an effect of warm water foot soak therapy on changes in blood pressure in third trimester pregnant women

Researchers believe that hydrotherapy with a temperature of $40^{\circ}$ $43^{\circ}$ can help lower blood pressure in pregnant women with hypertension effectively because it can be done at home and cheap. At the time of the study some pregnant women said the warm water used was appropriate, not too cold and not too hot. In addition to lowering blood pressure, hydrotherapy with warm water can provide calm, relaxation, reduce dizziness, feel lighter, and reduce aches.

Based on table 5, it can be seen that the Wilcoxon test shows that the average blood pressure value of pregnant women with hypertension before being given hydrotherapy is $141.82 \mathrm{mmHg}$ systolic, and $89.09 \mathrm{mmHg}$ diastolic. The mean value of blood pressure for pregnant women with hypertension after being given hydrotherapy were systolic at 136.64 $\mathrm{mmHg}$ and diastolic for $84.91 \mathrm{mmHg}$. So that the difference between the decrease in blood pressure of pregnant women and hypertension is $5 \mathrm{mmHg}$ systolic and 4 $\mathrm{mmHg}$ diastolic. From these data it can be 
seen that there is a decrease in blood pressure of pregnant women with hypertension after being given hydrotherapy. Systolic blood pressure in respondents after being given hydrotherapy all decreased (100\%), while the diastolic blood pressure of 8 people $(72.7 \%)$ experienced changes, and as many as 3 people (27.3\%) did not change. The results of the Wilcoxon test showed that the systolic $\mathrm{p}$ value of $0.003(<0.05)$ and diastolic $\mathrm{p}$ value of $0.011(<0.05)$, so that statistically there was a significant difference before and after the intervention on systolic and diastolic blood pressure.

This research is in line with Sabattani et al. In 2016, where the results showed that after soaking the feet with warm water at $39^{\circ}$ for 15 minutes it had an effect on the blood pressure of pregnant women with preeclampsia. This statement can be seen from the $p$ value of 0.0001 ( $\leq$ 0.05 ), then $\mathrm{HO}$ is rejected and $\mathrm{Ha}$ is accepted, meaning that there is an effectiveness of foot soaking with warm water on reducing blood pressure in pregnant women with preeclampsia Sabattani, C. F., Machmudah \& Supriyono, (2016). The researcher believes that hydrotherapy with a temperature of $37^{\circ}-$ $39^{\circ}$ can be given to hypertensive pregnant women whose blood pressure is not too high $(<160 / 100 \mathrm{mmHg})$. Some respondents said that the temperature of $37^{\circ} \mathrm{C}-39^{\circ} \mathrm{C}$ was not warm enough. Respondents who do not experience changes in blood pressure may be due to the open room, environmental conditions that are too much wind that disturbs the water temperature, respondents are too tense, talk a lot during therapy.

Based on table 6 in the MannWhitney test, it is obtained p $0.000(<0.05)$ so that statistically there is a significant difference in the decrease in systolic blood pressure. Based on the Mann-Whitney test in Table 7, it is obtained p $0.013(<0.05)$ so that there is a statistically significant difference in the decrease in diastolic blood pressure. It can be concluded that this study showed a difference in systolic and diastolic blood pressure in the hydrotherapy group with a temperature of $40^{\circ}-43^{\circ}$ compared to a temperature of $37^{\circ}-39^{\circ}$.

This research is supported by Putri, Kristiani \& Sonhaji, (2015). Based on the statistical test of the Mann-Whitney test, it is known that the p-value is 0.004 . Where the $\mathrm{p}$-value $<=(0.05)$, it can be concluded that the reduction in systolic blood pressure in the intervention group with foot soak treatment using warm water and elderly exercise was more effective than the control 
group with elderly exercise alone. Researchers argue that the warmer the water used is with a temperature of $40^{\circ}-43^{\circ}$ , the greater the decrease in blood pressure experienced by pregnant women with hypertension. Hydrotherapy with a temperature of $40^{\circ}-43^{\circ}$ can be given to hypertensive pregnant women to lower blood pressure, while at temperatures of $37^{\circ}$ - $39^{\circ}$ can be given to pregnant women to be more relaxed and reduce complaints such as aches. There are several factors that can influence this research, namely the atmosphere during hydrotherapy, pregnant women are required to calm down, lean back on their body and head, close their eyes, and regulate their breathing. It would be better during hydrotherapy given soothing aromatherapy and hypnotheraphy with positive affirmations. Therapy is better done in a closed room that has been prepared so that the water temperature can last longer. The time for hydrotherapy can be carried out in the afternoon or evening when the mother is not doing household activities such as in the morning to make it more effective.

\section{Conclusion}

Based on the results of the research and discussion that has been submitted, the researcher can convey the following conclusions Most pregnant women with hypertension experience gestational hypertension, aged 20-35 years, and are multiparous, There is a difference in blood pressure (systolic and diastolic) before and after the intervention in the hydrotherapy group with a temperature of $40^{\circ}-43^{\circ}$, There was a difference in blood pressure (systolic and diastolic) before and after the intervention in the hydrotherapy group with a temperature of $37^{\circ}-39^{\circ}$ and The decrease in systolic and diastolic blood pressure in the hydrotherapy group with a temperature of $40^{\circ}-43^{\circ}$ was greater than the temperature of $37^{\circ}-39^{\circ}$.

\section{Suggestion}

Based on the results of the conclusions above, the researcher can submit suggestions to several parties as follows It is hoped that the Health Primary Care can improve facilities and infrastructure such as hydrotherapy banners and leaflets, digital water thermometers, and stainless steel kits, to support the handling of complications of early pregnancy with hydrotherapy for pregnant women with hypertension. It is hoped that midwives can apply this research by increasing knowledge and providing 
demonstrations about hydrotherapy to pregnant women with hypertension. The results of this study can be continued by using other methods and increasing the frequency of hydrotherapy to determine a steady decrease in blood pressure. Future research will be better if the place of therapy is well prepared.

\section{Reference}

Alkema, L. et al. (2016). Global, Regional , and National Levels and Trends in Maternal Mortality Between 1990 and 2015 , with Scenario-based Projections To 2030 : A Systematic Analysis by The UN Maternal Mortality Estimation Inter-Agency Group', The Lancet. World Health Organiza. Elsevier Ltd/Inc/BV. All rights reserved, 387, 462-474. https://doi.org/10.1016/S01406736(15)00838-7

Arikunto, S. (2010). Procedur Penelitian Suatu Pendekatan Praktik. Rineka Cipta.

Dahlan, S. (2017). Statistik Untuk Kedokteran dan Kesehatan: deskriptif, bivariat dan multivariat, dilengkapi aplikasi dengan menggunakan SPSS. (6 th). Epidemiologi Indonesia.

Dilianti, I. E., Candrawati, E. \& W, R. C. A. (2017). Efektivitas Hidroterapi Terhadap Penurunan Tekanan Darah Lansia Penderita Hipertensi Di Panti Wreda AlIslah Malang. Nursing News, 2, 193-206.

https://publikasi.unitri.ac.id/index.php/ fikes/article/view/579
Fadlun and Feryanto, A. (2011). Asuhan Kebidanan Patologis. Salemba Medika.

Imaroh, I., Nugraheni, S. \& D. (2018). Faktor Risiko Yang Mempengaruhi Kejadian Hipertensi Pada Ibu Hamil Di Wilayah Kerja Health Primary Care Kedungmundu, Kota Semarang Tahun2017. Jurnal Kesehatan Masyarakat, 6(2), 570-580.

Jumaiza, Elvira, D. \& Panjaitan, A. (2018). Analisis Faktor-faktor yang Berhubungan dengan Kejadian Hipertensi Pada Ibu Hamil Trimester III.

LeMone, P. \& Burke, K. (2008). MedicalSurgical Nursing : Critical thinking in client care (4 th edn). Pearson Practice Hall.

Medforth, J. et al. (2015). Kebidanan Oxford dari Bidan untuk Bidan. EGC.

Ministry of Health. (2017). PROFIL KESEHATAN INDONESIA. Kementrian Kesehatan Republik Indonesia.

Nurahmandani, A. R., Hartati, E. \& Supriyono, M. (2016). Efektivitas Pemberian Terapi Rendam Kaki Air Jahe Hangat Terhadap Penurunan Tekanan Darah Pada Lansia Dengan Hipertensi di Panti Werdha Pucang Gading Semarang. Ilmu Keperawatan dan Kebidanan.

Perry, P. \&. (2010). Buku Ajar

Fundamental Keperawatan (7 th edn). EGC.

Putri, A., Kristiani, E. \& S. (2015). 
Efektifitas Terapi Rendam Kaki Menggunakan Air Hangat Dan Senam Lansia Terhadap Tekanan Darah Di Unit Rehabilitasi Sosial (URESOS) Pucang Gading Unit Semarang II.

Rahim, R., M, S. S. \& Rismawati, S. (2015). Pengaruh Rendam Kaki Air Hangat Terhadap Perubahan Tekanan Darah Ibu Hamil Hipertensi.

Robson, S. E. \& Waugh, J. (2013). Patologi Pada Kehamilan Manajemen \& Asuhan Kebidanan. EGC.
Sabattani, C. F., Machmudah \& Supriyono, M. (2016). Efektivitas Rendam Kaki dengan Air Hangat Terhadap Penurunan Tekanan Darah Pada Ibu Hamil Penderita Preeklamsi di Health Primary Care Ngaliyan Semarang. jurnal Ilmu Keperawatan dan Kebidanan, 1.

Sugiyono. (2015). Metode Penelitian Kuantitatif, Kualitatif Dan $R \& D$. Alfabeta.

WHO. (2018). Maternal mortality. 